\title{
QUALITY MANAGEMENT CONCERNING USE OF ICT IN HIGHER EDUCATION LANGUAGE LEARNING ENVIRONMENTS: A CASE STUDY IN TURKEY
}

\author{
Başak Ercan \\ Akdeniz University, Turkey
}

\begin{abstract}
Globalization and technology have changed educational settings, and information and communication technology (ICT) literacy has become inevitable in this new era of teaching and learning. ICT is believed to help to transfer educational environments into learnercentered ones and to enhance the quality of teaching learning and management in education. Over the last fifteen years, Turkish education system has been undergoing some reforms both in schools and universities, trying to equip education settings with at least a projector, a computer and Internet access. The survey presented in this article examines language teachers' beliefs and attitudes towards ICT in teaching English at a state university. It aims to better understand the challenges teachers face in integrating ICT in teaching and learning and thus to search for the answer to the question 'What are the main components of quality management in ICT use in higher education language learning settings?'. A semi-structured interview and focus group discussions were used to collect data. Twenty-eight teachers participated in the survey and the results showed that the majority of the participants had positive attitudes towards the integration of ICT in language learning environments; yet some of the teachers found the practice not that easy concerning finding the most suitable materials while preparing and delivering lessons. They also stated that their lack of classroom management skills, bad student behavior hindering learning and students' lack of using ICT made the integration of ICT into education settings quite challenging and added that the lessons were quite short to implement ICT strategies appropriately. Another noteworthy result was that the majority of the teachers' understanding of effective use of ICT in class seemed rather limited and unproductive. Therefore, the teachers were looking for support from the management to provide them with the required equipment and technical support when necessary. They also needed exchange of experience in learning of ICT skills in language teaching, which all showing that quality management in ICT use needs developing. Concerning all these, the researcher suggests ideas to improve the quality management in ICT use in language learning in higher education institutions.
\end{abstract}

Keywords: education managers, EFL instructors, ICT use in language teaching, language learning environments, quality management. 


\section{Introduction}

Information and Communication Technologies (ICT hereafter) have made learning environments very powerful in that education settings and training courses have turned into open-space learning cycles (Burke \& Fedorek, 2017; McCarthy, 2017). Therefore, education management systems are required to enhance the use of ICT and to manage the strategic changes in order that learner outcomes rise in today's modern world.

ICT is defined as a set of technological tools and resources used to communicate and to create, disseminate, store, and manage information (Tinio, 2003). ICT use is supported by the European Council as well. For example, one of the operational goals of Erasmus (European Commission, 2006) promoting the attainment of European Space for Higher Education by reinforcement of training and innovation is to support the development of contents, services, pedagogies, and innovative lifelong learning practices based on ICT.

A well-balanced ICT environment is likely to enable students to feel and stay motivated (Bilyalova, 2017) throughout the learning process. Motivation, individualization, learning in context and the activation of the learner are often a part and a parcel of a successful ICT support (Mullamaa, 2010). Wright (2008) states that academic learning accompanied by computer technology offers students much more confidence and interest in the process of exploring and learning knowledge. It also helps to create the $21^{\text {st }}$ learning environments where students need to possess skills of cooperation, communication, critical thinking, problem-solving and reflection (Buchem \& Hamelmann, 2011; Gunuç, 2016; Rotherham \& Willingham, 2010).

In education, quality means better learner outcomes, which is possible by creating a quality culture in the institution. To achieve the desired results, education managers must question core teaching and learning processes and methods and that needs to be a shared vision throughout the whole organization, which could be achieved through good quality management skills. Quality management provides a connection between outcomes and the process by which outcomes are achieved (Frazier, 1997) and it requires autonomy, capability, and creativity (Lowther et al. (2008).

\section{Foreign Language Education and ICT}

In the $21^{\text {st }}$ century, continuous advances in technology determine how to learn and teach like in every other field. Therefore, technology integration has also gained importance in language learning. ICT integration into teaching and learning process gets far more important in non-English speaking countries because it provides learners with authentic materials inside and outside the classroom and gives learners a better understanding of the target culture allowing them to have interaction opportunities and 
feedback (Golonka et al., 2015), which is the core of constructivist learning theory (Vygotsky, 1978). Then arises the challenge for the education managers and teaching staff to develop an action plan through which current understanding of second/foreign language learning and teaching can be applied and developed (Grabe \& Grabe, 2005).

In a classroom, the teacher perceives and defines a teaching situation, makes judgments and decisions, and then takes related action (Chen, 2008); thus, he/she has an important role to play ensuring the successful implementation of ICT in educational environments (Çelik, 2013; Çelik et al., 2013; Gilakjani \& Leong, 2012), which requires today's language teachers to be proficient in the target language and sufficiently trained to able to leverage the opportunities provided by ICT (Godwin-Jones, 2015). It is of crucial important to actively involve students into ICT integrated lessons such as by giving responsibilities such as tasks, homework, and projects. Teachers, through these processes, need to guide students in self-directed learning, as well. Self-directed learning skills enable students to take control of their learning activity through their autonomous learning (Bowers, 1987) of online content anywhere, anytime, thereby increasing education efficacy (Warschauer, 1997; Zainuddin \& Perera, 2018).

The International Society for Technology in Education (ISTE, 2008) describes the effective teachers' use of ICT in class as follows:

- Facilitate and inspire student learning and creativity;

- Design and develop digital age learning experiences and assessments;

- Model digital age work and learning;

- Promote and model digital citizenship and responsibility;

- Engage in professional growth and leadership.

Higher education in Turkey has a great place in terms of teaching foreign languages. A great majority of the universities offer yearlong intensive English language classes to their students so that they will be able to follow lessons in English in their major programs, so it is important to specify the current situation of ICT integration into language learning and teaching, concerning its benefits in language teaching and learning. There is not much in the literature about English language instructors' beliefs and attitudes towards the use of ICT in their classrooms and how they integrate it, if applicable, into their lessons in higher education in Turkey. This current study also focuses on the barriers language teachers perceive or face when they are trying to integrate ICT into their education contexts based on their pedagogical and instructional beliefs and thus what educational managers could do to improve the situation for better in the frame of quality management, emphasizing the significance of knowing how to integrate these technologies into learning environments and to manage them in an efficient and effective way to level up learning outcomes. 


\section{The Case in Turkey}

In Turkey, English Language Teaching (ELT) programs include a course entitled 'Information Technologies'; yet this course focuses on how to deal with technology rather than how to implement ICT into teaching and learning environments. However, pre-service teachers need hands-on experience in designing and teaching technology integrated lessons; then the need of curricula change arises to keep pace with changes in today's technology enhanced student-centered learning environments. In primary and secondary education, Ministry of Education (MoNE, 2015) started Fatih project in 2011, which aimed at equipping schools with good infrastructure and tablets by the end of 2014 to build a national network; yet the e-content of the project displayed compatibility with the national curriculum, the syllabi, and the core materials to some extent (Kizilet \& Özmen, 2017) and unfortunately not much was done for the training of teachers to implement technology into classrooms; therefore, the project has not yielded the expected results. As to tertiary education concerning state universities, technological infrastructure is much better, and some universities provide their academicians with personal computers. However, the problem of how to integrate technology into teaching practice keeps its place as an issue.

\section{Barriers to ICT Implementation into Language Learning Environments}

ICT bring together traditionally separated educational technologies, books, writing, telephone, television, photography, databases, games, and more, bridging forms of knowledge and literacy. However, apart from these opportunities, they also bring challenges to be overcome: to embed ICT in teaching and learning environments, teacher training, curriculum structures and materials, classroom practices and the ways of assessment need to go in revision at all levels (Livingstone, 2012). Tinio (2003) also points out that "the effective integration of ICT into the educational system is a complex, multifaceted process that involves not just technology but also curriculum and pedagogy, institutional readiness, teacher competencies, and long-term financing, among others (p.5)."

University teachers and teaching staff encounter demanding challenges when they are integrating ICT into their teaching practice. They not only need to learn how to use ICT in teaching, but they also need to use ICT in pedagogically meaningful ways (Ertmer \& Ottenbreit-Leftwich, 2010; Harris \& Rea, 2009; Löfström \& Nevgi, 2008). Löfström \& Nevgi are of the view that lack of motivation could be the mere reason of not applying ICT into teaching and learning environments. Believing that changes are too fast and not having a positive view of the effectiveness of ICT are other factors which discourage teachers to use ICT in their teaching style (Bennett 
\& Bennett, 2003; Zare-ee, 2011). Çuhadar \& Yücel's (2010) study points out that a lack of technological infrastructure, technical problems while using ICT, a lack of knowledge and experience of using ICT, not being able to follow the latest updates about ICT and a lack of self-confidence about implementing ICT into teaching practice are factors stated by pre-service EFL teachers.

As to the roles of education policy makers, they need to take good examples for embedding ICT into teaching and learning environments. For example, in Norway, ICT use is of great importance in teaching English Teacher education programs where national curricula require student teachers to master the use of ICT for teaching subject disciplines in a competent and professional manner (Almås \& Krumsvik, 2007). In Colombia, in accordance to the curriculum for the Master's program in English Language Teaching, Technological Environments, one of the competences, is a crucial part of the program which facilitates the creation of autonomous learning environments by using ICT, so that each candidate in the Master's program will have to know how to use new ICT tools based on the requirements of the context, propose strategies in order to respond to the learning needs of their students in order to support them with the technological tools at hand and to understand the major challenges posed by meeting the changing educational needs of the society (McDougald, 2013). Likewise, in Chinese higher education institutions, English is a compulsory course from undergraduate to doctoral students. To improve continuously the English teaching and learning effectiveness and efficiency, some Chinese universities have developed web-based instruction systems for EFL teaching (Liu \& Yu, 2012). When looking at all these examples, the ELT programs in Turkey need to renew their programs concerning ICT integration into language learning environments in order to stay in alignment in modern world's education settings.

\section{Method}

This survey is a qualitative research in nature to ensure better understanding of the challenges the teachers face in integrating ICT in teaching and learning and thus to search for the answer to the question 'What are the main components of quality management in ICT use in higher education language learning settings?' For this purpose in mind, the following research questions are stated:

1. What are EFL instructors' attitudes and beliefs towards the integration of ICT in their teaching practice?

2. How do EFL instructors integrate ICT into their teaching practice, concerning four language skills? 
3. What are the barriers which hinder EFL instructors integrating ICT into their teaching practice?

A semi-structured interview was used to examine 28 EFL instructors' beliefs and attitudes towards the use of ICT in English language teaching and their perceptions of the factors discouraging them to implement ICT in language learning environments. The participants were chosen randomly from a School of Foreign Languages at a state university in a traditional face-to-face learning environment. Data was also gathered through focus group discussions and analyzed using context analysis, which involved developing codes, categories, identifying themes and developing concepts (Denscombe, 2007). After the context analysis, selected instructors' opinions were given in quotations. In order to respect the anonymity and confidentiality of the interviewees, the quotes are given without mentioning the names. The significant parts from the focused group discussions were also placed in the study.

The researcher made face-to-face interviews and two focus group discussions in fall semester of 2020-2021 Academic Year. The researcher also consulted two other field experts about the questions on the semi-structured interview. Each interview lasted approximately 25-30 minutes and the focus group discussion lasted for about one and half hour. The interviews and discussions were recorded. Then, the recordings were deciphered and encoded after some themes. One qualitative analysis expert was asked of their opinions concerning the codes and themes respectively and a consensus was achieved based on Miles \& Huberman's (1994) formula.

As to the participants and the infrastructure of the institution, the instructors were familiar with the use of ICT and each class was equipped with a computer, a projector, and a sound system as well as Internet access. Students registered at this prep school are also allowed to access the Internet with their own smart devices. Yet there are not any supporting facilities or resources such as language labs and self-access centers in the school of foreign languages where students can study individually.

\section{Results and Discussion}

In this paper, the researcher obtained some important results pertinent to the use of ICT in language classrooms. The literature review indicated that the use of ICT enhances the learning process; yet there are some obstacles to be put out off the way, which could be realized with a good quality management. Based on the first research question 'What are EFL instructors' attitudes and beliefs towards the integration of ICT in their teaching practice?', it is seen that instructors have a positive attitude towards ICT enhanced lessons, and they think that lessons are more motivating and 
attractive for students and language skills develop quicker, adding that it is very important to provide students with authentic material. Some of the responses are as follows:

"Embedding media technologies into my lessons are more motivating, meaningful and enjoyable for my students. ICT provides lots of different materials for us, as teachers to use in our classes. It helps us keep up to date with the latest teaching trends. It also provides individual and interactive exercises for students."

"ICT makes planning easier and helps save time and energy while delivering a lesson."

"ICT is very useful to find authentic material, which is really important for students to be exposed to the target language in a non-English speaking environment. Students are also familiar with the technology, so they get attracted and focus more on what's happening."

Likewise, Park and Son's (2009) research showed that teachers have positive attitudes towards the use of computers in the classroom and they consider computer technology as a useful teaching tool that can enhance ways of teaching by offering students a variety of language inputs and expanding students' learning experiences in real and authentic contexts. According to Çobanoğlu \& Yücel's (2017) study done at another state university in Turkey, EFL instructors have positive attitudes towards the use of ICT, and they integrate ICT into their teaching practice while preparing and delivering their lessons. They especially prefer to prepare attractive PowerPoint presentations containing music and visual items. As a result, the results of this qualitative study coincide with those of the other studies.

As to negative sides, a few teachers pointed out that some of the students are negatively affected by the use of technology in class. As one of the teachers stated:

"Some students are less willing to read and write because of the advancements in technology. For example, they prefer taking the pictures of the board instead of taking notes."

On the other hand, some participants also think that there are some challenges for them to incorporate ICT into their teaching practice. They mostly claim that it is not easy to find suitable supplementary materials and some resources are unreliable. As stated by some of the instructors:

"When there are too many materials, it might take a long time to decide on the most appropriate ones."

"Internet provides a wide range of resources and unfortunately some of them are not reliable. It is also difficult to choose which ones to use in my lessons." 
"There are a lot of materials and you need to better differentiate which ones are better and how much you need because using it too much can also be boring for students."

Another challenge for implementing ICT into learning setting is that teachers and learners find it difficult to choose among the wide variety of Internet resources to benefit themselves the most (Postholm, 2007). Then, it is where both the teachers and learners need effective guidance to use technology in an effective and meaningful way to find ways of reducing cognitive load and to support learners in constructing meaningful knowledge. Since the technology allows access to multimedia resources, it is highly important to deliver lessons in a pedagogically useful way. Then the learners feel more relaxed to learn, and they also become more active because they learn by using technology rather than by being instructed by technology (Grabe \& Grabe, 2005).

When considering the second research question, 'How do EFL instructors integrate ICT into their teaching practice?', the results revealed that instructors use a wide range of sources such as blogs, forums, websites to access authentic materials and exercises when preparing their lessons. As stated by some of them:

"I check some blogs and forums written by teachers from different parts of the world. I adopt those teaching ideas to my lessons."

"I use the Internet to search for suitable material such as images, texts, exercises and so on. I also prepare PowerPoint presentations."

"I find images, videos, interviews, documentaries, songs and news related to the topics in our course book."

"Internet is a great source for finding listening tracks, videos or exercises. It is indispensable for me. I use it about every day when preparing a lesson. I google and find what I want on the net."

"I prepare my lessons as PowerPoint presentations. When preparing them, I use blogs, visuals, audios...etc. I find online. It is much easier that way and practical, too, concerning weak or no Internet access from time to time."

Apart from the interviews, in focus group discussions, it appears that most of the teaching staff encourage their students to use ICT inside and outside the class to some extent. They use some applications to attract their attention and to motivate them to participate in the lesson. They also allow their students to use online dictionaries on their smart phones and to interact with each other by playing online games. Apart from these, some of the teachers would like the students to submit their assignments through email. All the teachers use the supplementary digital material of the course books. There are some responses and comments from the instructors below: 
"I let students use their mobile phones as a dictionary."

"I ask students to email their written and oral assignments. Some websites like Kahoot and lyrics training are quite fun when students are bored. I-tools of the course books provide good materials as well."

"I use I-tools of the book. I also use YouTube videos or music during lessons."

"I either use PowerPoint presentations, videos or I-tools of the course book."

"I integrate videos, tracks, photos, speeches and so on into my lessons."

"I make use of PowerPoint presentations, online exercises, videos and I-tools of the course book.

"During the lesson I use online exercises if students need. We watch videos related to the subject they study. We sometimes watch TV series with English subtitles. Apart from these, if I need an urgent answer to a question, I look it into on the Net. I also use online dictionaries and encourage my students to do so as well."

"I have everything prepared, downloaded prior to my lessons. I rarely use the Internet during lessons. But when I do, it is for the use of applications on students' smart phones e. g. Kahoot and Quizlet."

"Websites, mobile phone applications that can be used in class, e-books and learning management systems of the course books are the ICT tools I use in my classes."

"I use the Internet in class, we play some online games, and students interact with each other using their mobile phones. I also use the I-tools of the course books. I use some relevant websites and pages to broaden their thoughts."

Upon on skill-based dimension, instructors integrate ICT into their teaching practice as follows:

\section{Listening:}

"I use videos, songs with gap-filling exercises, some short films with English subtitles."

"I try to find authentic materials. BBC, British Council and some other websites include good material such as videos, podcasts “

"I slow down or speed up videos. Do online listening tests. Find authentic listening material.

\section{Speaking:}

"I use photos and videos as speaking prompts. I also ask them to prepare presentations using Powerpoint or Prezi."

"After watching videos or looking at photos or pictures from the internet, we talk about the topic."

"I try to show videos including target language." 
"Students record videos or make interviews by using their mobiles or other devices. They upload the videos on their social network profiles or send them via WhatsApp."

\section{Reading:}

"I use PowerPoint presentations to work on reading texts. They help me to better focus on a reading skill at a time."

"I assign students to read some texts and news related to the given topic on Internet and in the next lesson I ask them to share what they have read." "I use the projector to project a reading skill exercise."

\section{Writing:}

"I show my students some sample essays. They email their essays to me. They also have a WhatsApp group as a class and they chat in English." "I get my students to write film reviews after movie hours."

"I try to present sample pieces related to the writing as much as possible." "After watching videos or looking at photos or pictures from the internet, we write about the topic."

"Showing online samples and writing about a topic from a visual or audio text."

"If students need, we examine some writing samples such as paragraphs or essays. They read some samples, and this encourages them to write. They also send their writing pieces via email, and I give them feedback on a digital platform, too."

Comparing to teaching speaking, reading, and writing, the majority of the teachers use ICT rather effectively while teaching listening skills. A few teachers expressed that they never use ICT for the purpose of teaching writing skill to their students.

As to the third research question of this study, 'What are the barriers which hinder EFL instructors integrating ICT into their teaching practice?', the survey revealed that the teaching staff mostly complain about weak Internet access in the classrooms. They think that it is difficult to access some technical devices in classroom settings and when facing a problem, it is waste of time dealing with it. Moreover, technology might be challenging to use for some teachers. Lack of student interest at some points and bad student behavior are other challenges to overcome according to the teachers. Finding enough time to implement ICT into lessons concerning the intense curriculum is another challenge for some teachers. A few instructors also state that they do not have the required classroom management skills while integrating ICT into their teaching practice, causing them to feel uncomfortable.

"I have poor classroom management skills while using ICT in my classes." "Some students are not familiar with high-tech environments, and they have bad skills in the use of ICT." 
Some teachers also state that they have lack of interest in integrating ICT into their teaching practice and find traditional methods much more practical and appropriate for teaching English. Some of them also think that lessons are too short to implement ICT into learning settings.

Moreover, external factors such as lack of time, insufficient computer facilities, rigid school curricula and textbooks and lack of administrative support negatively influence the implementation of technology in the classroom. Internal factors such as teachers' limited digital skills, knowledge about computers and beliefs and perceptions of technology use also seem to affect significantly teachers' decision to use ICT (Park \& Son, 2009). The findings of a study by $\mathrm{Hu}$ and McGrath (2011) indicate that limited ICT skills and pedagogic expertise are obstacles to the use of ICT in the English language teaching. According to Salehi \& Salehi's (2012) study, insufficient technical support at schools and poor access to Internet and ICT prevent teachers to use ICT in the classroom. A lack of motivation, and technical and financial support are other barriers ELT teachers face when implementing ICT into their learning settings (Liu \& Szabo, 2009). Shortage of class time is another important discouraging factor for the teachers to integrate ICT into the curriculum. Moreover, teachers also refrain from using ICT concerning the time factor to learn those required skills.

Generally speaking, in response to the research questions stated, the findings suggest that although teachers use a wide range of sources to integrate ICT into the teaching of English, it seems that mostly learning from ICT strategies are in use rather than learning with ICT strategies. Based on this survey, ICT is not effectively used by most of the EFL teachers, and they think that the learning management supplement of the course book gives them enough chance to integrate ICT into their teaching practice. They find it very handy in that they can project the course book on the screen, and they can cover the units and do all the exercises at a click of the mouse, including workbook and teacher's book.

When the use of ICT in teaching and learning languages is taken into consideration from the angle of education management, the education policy in Turkey needs revising. Apart from training language teachers and renovation of language teaching programs, a quality culture where an ICT policy defines and search for ways how ICT will be helpful improving teaching and learning.

\section{Conclusions}

There is no doubt that effective ICT integration into educational settings does not depend on only one variable. The infrastructure of the educational institutions, the teachers' pedagogical beliefs and the curriculum in 
progress all define the direction of the effective use of ICT in classrooms. Although instructors mostly believe the good impact of ICT use in learning environments, they need to attend in-service training and/or professional development programs to train themselves. Instructors also need to support students for ICT use in and outside class. If used effectively and efficiently, ICT can be used for self-access learning by students so that they can better improve their language skills.

This study is a relatively small-scale study with a limited number of participants only from one state university in a face-to-face learning environment by using a qualitative methodç. Therefore, further studies need to be carried out by using a mixed-method approach. Also, more research needs to be done to find out the barriers English language instructors point out to integrate ICT in their lessons and thus to propose solutions for those problematic areas. Other studies should be carried out to measure instructors' ICT competences and what is being done in the frame of quality management in other higher education language learning environments.

The ELT programs in Turkey need to be renewed by transferring into an ICT integrated curriculum, instruction, and professional development programs. Instructors are required to alter the way they teach concerning the improvements in technology so that learners are provided with new learning styles which could lead them to become more self-directed learners. This could be possible with creating a quality culture in the institution.

This study does not claim that ICT is the only and the best way to teach and learn a foreign language; however, it would not be wise not to get the benefits of integrating technology into language learning environments. Another important issue is that having the skills of using ICT does not necessarily mean that it is being put into teaching practice effectively; therefore, there is no doubt that implementing ICT into teaching and learning English depends on instructors developing their technological content knowledge and how they apply technology in the classroom as a pedagogical tool. This requires a needs analysis concerning the ICT use of the EFL instructors so that they could get proper in-service training or attend continuous professional development programs. It is also essential that related innovations be made to better applying good quality management skills throughout the whole institution and creating a shared vision to integrate ICT use into ELT programs which would pave the way for the programs of intensive language programs of the school of foreign languages to revise their curricula. 


\section{References}

Almås, A. G., \& Krumsvik, R. J. (2007). Digitally literate teachers in leading edge schools in Norway. Journal of In-Service Education, 33(4), 479-497.

Bennett, J. \& Bennett, L. (2003). A review of factors that influence the diffusion of innovation when structuring a faculty training program. Internet and Higher Education, 6, 53-63.

Bilyalova, A. (2017). ICT in teaching a foreign language in high school. Procedia- Social and Behavioral Sciences, 237, 275-281.

Bowers, R. (1987). Language teacher education: An integrated approach. In R., Bowers (Ed.), Language Teacher Education: An Integrated Programme for ELT Teacher Training (pp. 3-9), London, UK: Modern English Publications in association with the British Council.

Buchem, I., \& Hamelmann, H. (2011). Developing $21^{\text {st }}$ century skills: Web 2.0 in higher education - A case study. eLearning Papers 24, 1-4. Retrieved October 8, 2011 from http://www.elearningeuropa.info/files/media/media25535.pdf.

Burke, A. S. \& Fedorek, B. (2017). Does "flipping" promote engagement?: A comparison of a traditional, online, and flipped class. Active Learning in Higher Education, 18(1), $11-24$.

Çelik, S. (2013). Internet-assisted technologies for English language teaching in Turkish universities. Computer Assisted Language Learning, 26(5), 468-483.

Çelik, S., Arıkan, A. \& Caner, M. (2013). In the eyes of Turkish EFL learners: What makes an effective foreign language teacher? Porta Linguarum, 20, 287-297.

Chen, C. H. (2008). Why do teachers not practice what they believe regarding technology integration? The Journal of Educational Research, 102(1), 65-75.

Çobanoğlu, A. A. \& Yücel, Z. E. (2017). EFL teachers' technology use and attitudes towards information and communication technologies in education. Journal of Higher Education and Science, 7(3), 441-452.

Çuhadar, C. \& Yücel, M. (2010). Yabancı dil öğretmeni adaylarının bilgi ve iletişim teknolojilerinin öğretim amaçlı kullanımına yönelik öz yeterlik algıları [Pre-service language teachers' self-efficacy perceptions concerning the use of information and communication Technologies for teaching]. Pamukkale Üniversitesi, Eğitim Fakültesi Dergisi, 27, 199-210.

Ertmer, P. A. \& Ottenbreit-Leftwich, A.T. (2010). Teacher technology change. Journal of Research on Technology in Education, 42(3), 255-284.

Denscombe, M. (2007). The good research guide for small-scale social research projects. $3^{\text {rd }}$ ed. Buckingham, UK: Open University Press.

European Council, (2006). Recommendation of the European Parliament and the Council of 18 December 2006 on Key Competencies for Lifelong Learning, Official Journal of the European Union, 30 December, L394/10-18.

Frazier, A., (1997). A roadmap for quality transformation in education. Baca Ratan, Fla.: ST. Lucie Press.

Gilakjani, A. P., \& Leong, L-M. (2012). EFL teachers' attitudes toward using computer technology in English language teaching. Theory and Practice in Language Studies, 2(3), 630-636. 
Godwin-Jones, R. (2015). Contributing, creating, curating: Digital literacies for language learners. Language Learning \& Technology, 19(3), 8-20.

Golonka, E. M., Bowles, A. R., Frank, V. M., Richardson, D. L. \& Freynik, S. (2015). Technologies for foreign language learning: a review of technology types and their effectiveness. Computer Assisted Language Learning, 27(1), 70-105.

Grabe, M., \& Grabe. C. (2005). Integrating technology for meaningful learning. USA: Houghton Mifflin.

Gunuc, S. (2016). Students engagement at universities. Ankara: Nobel.

Harris, A. \& Rea, A. (2009). Web 2.0. and virtual world technologies: A growing impact on IS education. Journal of Information Systems Education, 20(2), 137-144.

Hu, Z. \& McGrath, I. (2011). Innovation in higher education in China: Are teachers ready to integrate ICT in English language teaching? Technology, Pedagogy and Education, 20(1), 41-59.

International Society for Technology in Education [ISTE], (2008). National Educational Technology Standards for Teachers. Eugene: ISTE Publications.

Kızılet, E. \& Özmen, K.S. (2017). ICT integration in Turkey: Evaluation of English language e-content of the FATIH Project. The Turkish Online Journal of Educational Technology, 16(4), 33-41.

Liu, Y. \& Szabo, Z. (2009). Teachers' attitudes toward technology integration in schools: A-four-year Study. Teachers and Teaching: Theory and Practice, 15, 5-23.

Liu, W. \& Yu, H. (2012). Effectiveness study of English learning in blended learning environment. Theory and Practice in Language Studies, 2(3), 524-530.

Livingstone, S. (2012). Critical reflections on the benefits of ICT in education. Oxford Review of Education, 38(1), 9-24.

Lowther, D. L., Inan, F. A., Strahl, J. D. \& Ross, S. M., (2008). Does technology integration work when key barriers are removed? Educational Media International, 45, 195-213.

Löfström, E. \& Nevgi, A. (2008). University teaching staff's pedagogical awareness displayed through ICT-facilitated teaching. Interactive Learning Environments, 16(2), 101-116.

McCarthy, J. (2017). Enhancing feedback in higher education: Students 'attitudes towards online and in-class formative assessment feedback models. Active Learning in Higher Education, 18(2), 127-141.

McDougald, J. S. (2013). The use of new technologies among in-service Colombian ELT teachers. Colombian Applied Linguistics Journal, 15(2), 247-264.

Miles, M. B. \& Huberman, A. M. (1994). An Expanded Sourcebook: Qualitative Data Analysis. Thousand Oaks, CA: Sage.

MoNE. (2015). Millî Eğitim Bakanlı̆ğ 2015-2019 Stratejik Planı [Ministry of National Education 2015-2019 Strategic Planning]. Ankara.

Mullamaa, K. (2010). ICT in language teaching - Benefits and methodological implications. International Education Studies, 3(1), 38-44.

Park, C. N. \& Son, J-B. (2009). Implementing computer-assisted language learning in the classroom: Teachers' perceptions and perspectives. International Journal of Pedagogies and Learning, 5(2), 80-101. 
Postholm, M. B. (2007). The advantages and disadvantages of using ICT as a mediating artefact in classrooms Compared to alternative tools. Teachers and Teaching: Theory and Practice, 13(6), 587-599.

Rotherham, A. J. \& Willingham, D. T. (2010). 21 ${ }^{\text {st }}$ century skills. American Educator, 34(1), 17-20.

Salehi, H. \& Salehi, Z. (2012). Integration of ICT in language teaching: Challenges and barriers. $20123^{\text {rd }}$ International Conference on e-Education, e-Business, e-Management and e-Learning IPEDR, 27, IACSIT Press, Singapore.

Tinio, V. L. (2003). ICT in education. United Nations Digital Library.

Vygotsky, L. (1978). Mind in Society. Cambridge, MA, Harvard University Press.

Warschauer, M. (1997). Computer-mediated collaborative learning: Theory and Practice. The Modern Language Journal, 81, 470-481.

Wright, J. M. (2008). Web-based versus in class: An exploration of how instructional methods influence postsecondary students' environmental literacy. The Journal of Environmental Education, 39(2), 33-46.

Zainuddin, Z. \& Perera, C. J. (2018). Supporting students' self-directed learning in the flipped classroom through the LMS TES BlendSpace. On the Horizon, 26(4), 281-290.

Zare-ee, A. (2011). University teachers' views on the use of Information and Communication Technologies in teaching and research. The Turkish Online Journal of Educational Technology, 10(3), 318-327. 